Disponível em:

http://editora.unoesc.edu.br/index.php/race

Race, Joaçaba, v. 14, n. 3, p. 863-888, set./dez. 2015

\title{
INDICATORS OF TECHNOLOGY IN THE PERCEPTION OF IT AND BUSINESS MANAGERS - A COMPARATIVE ANALYSIS
}

Indicadores de tecnologia na percepção de TI e de gerentes de negócios uma análise comparativa

Gustavo Hermínio Salati Marcondes de Moraes E-mail: gustavosalati@gmail.com Doutor e Mestre em Administração pela Fundação Getúlio Vargas; Professor da Faculdade de Ciências Aplicadas da Universidade Estadual de Campinas. Endereço para contato: Cidade Universitária Zeferino Vaz, Barão Geraldo, 13083970, Campinas, São Paulo, Brasil. 
Abstract

In this study we sought to identify how the indicators of information technology use can assist in the information technology governance and alignment of organizations through benchmarking. Multiple case studies were conducted in four large organizations that act in the service sector of vocational education, in which information technology plays a key role, interviewing executives from technology and business. The main indicators used in the study where the index G (expenditure and investment in IT / annual net sales) and the CAPT (annual cost per keyboard). As a result, it became clear that the indicators are perceived as important for information technology governance and alignment, and their own quality management, integrating corporate governance. Therefore, the indicators presented serve as management tools and a basis of comparison with other companies, the sector of activity, as a comparison of the historical evolution's own internal organization (monitoring) and as part of negotiation for future technology investments, providing support to the information technology managers and business managers, facilitating their decisions.

Keywords: Information technology. Indicators. IT governance.

\section{Indicadores de tecnologia na percepção de TI e de gerentes de negócios - uma análise comparativa}

Resumo

Neste estudo buscou-se identificar como os indicadores de tecnologia da informação podem auxiliar na governança e alinhamento de tecnologia da informação nas organizações por meio de benchmarking. Foram realizados estudos de caso em quatro grandes organizações que atuam no setor de serviços de educação profissional, em que a tecnologia da informação desempenha um papel fundamental, entrevistando executivos de tecnologia e negócios. Os principais indicadores utilizados no estudo foram o índice de G (gastos e investimentos em TI / vendas líquidas anuais) e o CAPT (custo anual por teclado). Como resultado, tornou-se claro que os indicadores são percebidos como importantes para a governança e alinhamento de tecnologia da informação, e sua própria gestão da qualidade, integrando a governança corporativa. Portanto, os indicadores apresentados servem como ferramenta de gestão e uma base de comparação com outras empresas, o setor de atividade, como comparação da própria evolução histórica interna da empresa (monitoramento) e como parte da negociação para investimentos futuros em tecnologia, prestando apoio a gerentes de tecnologia da informação e gestores de negócio, facilitando suas decisões.

Palavras-chave: Tecnologia de informação. Indicadores. Governança de TI.

\section{INTRODUCTION}

In a society undergoing rapid change, the competitiveness and continuous technological evolution charge of the organizations strategies and procedures to 
which information technology (IT) has been very much in demand, enhancing its role in business and administration.

The wide spread of IT in all sectors and its widespread use by most professionals in business, eventually merge and confuse the IT initiatives with business initiatives (BLOEM; VAN DOORN; MITTAL, 2006).

This scenario has received attention from scholars, becoming an object of research questions on assessing the value of IT as well as the impact of IT investments in organizations (MATLIN, 1979; WEILL; OLSON, 1989; BACON, 1992; FITZGERALD, 1998; DEHNING; DOW; STRATOPOULOS, 2004; LUNARDI; BECKER; MAÇADA, 2009; WU; STRAUB; LIANG, 2015).

Information technology enhances the ability of enterprises to survive in the actual highly competitive global marketplace, and it has become more and more evident. The effective use of IT, however, relies heavily on good IT governance (WU; STRAUB; LIANG, 2015).

Although it's common sense among executives that only a large investment in technology can bring competitive advantage to the company (MARCHAND, 2005). This sense disregards the influences that cultural and behavioral factors play in the use of new technologies.

The cost and investment in IT will be reflected in business performance through the process of IT use, reflected in products and IT services, which would imply an impact of the use, thus affecting the outcome of the company (DEVARAJ; KOHLI, 2002).

The management and organization in the use of Information Technology is essential to obtain the benefits of related investments (WARD; TAYLOR; BOND, 1996). This breadth of action, aiming to establish the added value to the enterprise requires that the responsibilities in IT decisions beyond the area of IT managers to call IT Governance (DE HAES; VAN GREMBERGEN, 2009).

Several studies in governance seek to show associations between arrangements or mechanisms of IT governance with the organization's performance. Characteristics of IT governance, encountered in the field, are related to indicators of business performance (WEILL, 2004; WEILL; ROSS, 2004; BROWN; GRANT, 2005). Studies of effectiveness, in turn, consider elements of a possible next chain of causes and effects, such as the quality of information or system, the use of the system, and the impact on user activity, as reflected in the organizational impact (DELONE; MCLEAN, 1992, 2003). 
Institutes such as Gartner Group and the Fundação Getúlio Vargas (FGV) conduct research on companies, providing indicators on the use of information technology that enable comparative parameters. Thus, the analysis of such information, companies can check their investment relative to the market dedicated to technology and dealing with competition.

Considering the 26th edition of Information Resources Administration of Fundação Getúlio Vargas - Escola de Administração de Empresas do Estado de São Paulo (FGV-EAESP), medium and large private national companies on average allocate $7,6 \%$ of net revenues over expenditures and investments in IT. In the same sample, it proved an annual cost per keyboard on average $\mathrm{R} \$ 29,100.00$, ie, all spending and investment that is behind the keyboard unit of business, involving all components above the point of view IT (MEIRELLES, 2015).

Given the importance and value of IT investments and spending, and concern about its governance, this scenario presents itself challenging for companies regarding which IT governance structure to adopt, as it leads to better performance from its use by organizations.

The key governance mechanisms that contribute to effective IT governance has been researching by many authors recently. Some studies are related to structural mechanisms (ALI; GREEN, 2012; BOWEN; CHEUNG; ROHDE, 2007; HUANG; ZMUD; PRICE, 2010; KARIMI et al., 2000; PRASAD; GREEN; HEALES, 2012) and others to relational mechanisms (ALI; GREEN, 2012; BRADLEY et al., 2012). Organizations knows that IT governance is important to the enterprise, but they are uncertain about how IT should be strategically aligned with corporate objectives (INFORMATION TECHNOLOGY GOVERNANCE INSTITUTE, 2009).

From a practical point of view, the research helps managers in decision making on the information technology, with a tool to compare the company's results with other companies and competitors, and follow the evolution of technology in the company.

From a theoretical point of view, research collaborates with studies in information technology governance, listing the use of technology indicators with existing technology governance models.

\section{RESEARCH QUESTION AND OBJECTIVES}

The use of indicators of IT use to support IT governance has not been a frequent action in business. Thus, identifying the benefits of this use for the 
Information Technology Governance (ITG) is important when attempting to process a ITG structured and aligned to business strategy, which represents added value and positive results.

The research question is: how the indicators of Information Technology use can assist in the information technology governance and alignment of organizations through benchmarking?

The specific objectives are: to ascertain the role of IT, identify the process of IT governance and identify key indicators of use of IT in the organizations surveyed in recent years.

\section{LITERATURE REVIEW}

The literature review for the assembly of the theoretical framework encompasses three main blocks: the role and alignment of IT, IT governance and indicators of IT use.

\subsection{ROLE AND ALIGNMENT OF IT}

In a society undergoing rapid change, competitiveness and continuous technological charge of the organizations strategies and procedures to which IT has been very much in demand, enhancing its role in business and administration.

The focus of research was devoted to people and their action through the available technologies (ORLIKOWSKI, 2000), also focuses on the role of IT, given the prominence achieved by the information in organizational strategies.

It is observed that IT makes the secondary role of administrative support, to assume a strategic position, it is IT that feeds and concentrates bank information from various areas, but also widen strategies (ORLIKOWSKI, 2000).

Thus, studies and administrative and academic publications have focused their research on this innovative role of IT, discussing investments and the aggregation of values they provide to businesses, as well as emerging opportunities for the application of IT, such as e-commerce and e- business (EVANS; WURSTER, 1999; PORTER, 2001).

However, the relationship between IT use and productivity mismatch on business results, showing that this fact is a consequence of the lack of alignment of business strategies and IT, as a continuous and dynamic process and not procedure 
only occasionally (HENDERSON; VENKATRAMAN, 1993). Developing competitive advantage by using technology alone is unlikely to be sustainable, IT have to be coupled with effective market and business strategies in order to win (BAROTO; ABDULLAH; WAN, 2012).

Only and exclusively the application of IT does not warrant adding value to business. This result has its dependence on the organization's ability to exploit this technology continuously. The role of IT and its importance in an organization interfere in most of the internal corporate affairs, deserving consideration the current and future strategic position of such factors (NEUMANN; AHITUV; ZVIRAN, 1992; BAROTO; ABDULLAH; WAN, 2012).

The strategic grid is a model among the various methodologies available, to determine the positioning of IT within the organizational structure. This model describes what the possible positions that IT can provide in an organization, depending on the present impact (existing IT applications) and the future impact (IT applications planned for the future) (MCFARLAN; MCKENNEY; PYBURN, 1983). Figures 1 shows the grid strategic.

Although the original concept of strategic alignment has been developed over a decade (MCLEAN; SODEN, 1977; MILLS, 1986; BRANCHEAU; WETHERBE, 1987; DIXON; JOHN, 1989; NIEDERMAN; BRANCHEAU; WETHERBE, 1991; WATSON; BRANCHEAU, 1991; HAN; HUFF, 1993; HENDERSON; VENKATRAMAN, 1996), seek alignment of business strategies and technology continues to be valuable to corporate executives (ROBSON, 1994; LUFTMAN; PAPP; BRIER, 1995; ROGERS, 1997; PAPP, 2004).

The Model of Strategic Alignment (HENDERSON; VENKATRAMAN, 1993) is composed of four quadrants with three components each. These twelve components define how each quadrant is aligned in relation to others. All components work together, thereby determining the degree of alignment of the organization. 


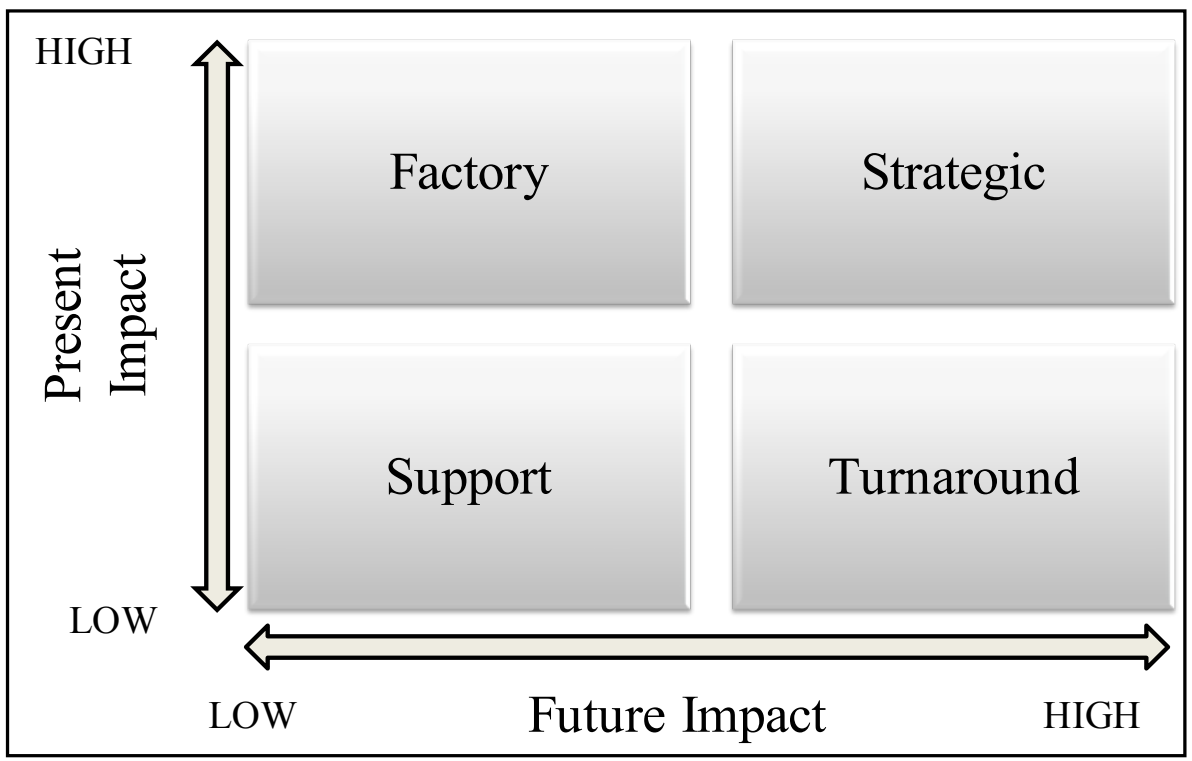

Source: adapted from McFarlan et al. (1983).

The areas of business and IT divide the model in which each has two sides, one strategy and other infrastructure.

According to the model, the business strategy positions the organization in relation to its external environment (market), while the strategy for Information Technology positions the organization in relation to the external environment (IT technology available, costs, suppliers, etc.) and infrastructure and IT processes and organizational adjustments relate to the internal rules for the implementation of the strategies formulated.

Is there a relationship between all sides, and such links are necessary because all parts and components should work as a whole unit. The vertical articulation of the model is strategic fit, which explains the need of the business decisions that will dictate their position in the market. The horizontal organization is the functional integration, which is more directly related to IT and business alignment. According to business change, change also the technology to monitor business processes. Such integration describes the ability of the company to position itself successfully in the market through the use of IT can bring competitive advantage and increase the value of IT (IVES; JARVENPAA; MASON, 1993; HENDERSON; VENKATRAMAN, 1996; PAPP, 2004). 
Some characteristics positively impact the strategic alignment between IT and business, they are: the ability to build and quickly change business applications to meet strategic needs, the connectivity of people, functional areas and applications of the organization and the ability of IT staff to work cooperatively (CHUNG; RAINER; LEWIS, 2003).

A low level of alignment between business strategies and IT executives can take the business to create their own IT departments, buying their own systems, feeding a database itself, which should contain redundant data to the corporate database (BRODBECK; HOPPEN, 2003).

It is therefore inefficient and redundant solution, with the consequences of rework and maximizing the cost.

\subsection{GOVERNANCE AND MANAGEMENT OF IT}

Although used interchangeably in the business environment, the terms governance and management have differences about the responsibilities involved, the roles and also the position within the organizational structure.

In administration, the term governance means coordinating, evaluating and planning, which is employed in the area of information systems or IT governance have the same responsibilities in order to obtain profit and success. Already the management, administration, has taken responsibility for operational decisions, while in the IT area, such decision making is to direct IT operations, aiming at a more efficient and effective for the organization (SOHAL; FITZPATRICK, 2002).

While those responsible for governance and create authorize the principles for management tasks, exercising authority in the organization, responsible for managing develop strategy, coordinate the resources, staff, maintenance, contract negotiations, among others (MITCHELL; SHORTELL, 2000; MEYER, 2004).

IT governance is broader than management. It is the implementation and transformation of IT in order to meet the present demands and future business (internal focus) and customers of these businesses (external focus), while IT management applies to the effective delivery of internal services and products IT and current operations (PETERSON, 2004). From the delegation conferred by those responsible for governance, executives exercising management (BIRD, 2001).

IT management and delivery of IT products and services can be performed by an outside supplier, while the IT governance organization is unique and can 
not be delegated to the market. IT governance is focused internally and externally, considering the present time and future. An IT governance used in a strategic way can be the key to the success of IT in the organization, describing the policies, structures and management processes, can be defined as a certain set of processes to ensure that IT support and maximize the goals and organization's strategies (SCHWARZ; HIRSCHHEIM, 2003).

In governance: focus on external and internal, higher levels of organization, strategy-oriented and future-oriented; while in management: internal focus, mid-level and operational organization, task-oriented and focused on the present (MITCHELL; SHORTELL, 2000).

Information technology governance is positively related to business performance through IT relatedness and business process relatedness (LAZIC et al., 2011). IT governance structures contribute to firm performance through IT-related capabilities which improve the effectiveness and efficiency of the internal business processes (PRASAD; GREEN; HEALES, 2012).

\subsection{INDICATORS OF IT USE}

A bibliographic review of IT Indicators in the literature suggests two bodies which carry out annual surveys to assist organizations in their decisions on IT by providing a consistent basis for comparisons.

These are: the IT Governance Institute (ITGI), highlighting some global indicators more generic IT governance, through research IT Governance Global Status Report (INFORMATION TECHNOLOGY GOVERNANCE INSTITUTE, 2003), published in 2008, the third consecutive year; and the Center for Applied Information Technology School Business Administration of São Paulo (FGV-EAESP-CIA), which held for 21 years the Annual Survey of Computing Resources in Brazilian companies, analyzing indicators of IT use very specific.

The IT Governance Institute (ITGI) was established in 1998 in recognition of the increasing importance of information technology for business success. In many organizations, success depends on the ability of IT to enable achievement of business goals. In such an environment, governance of IT is as critical as corporate governance or business. ITGI aims to be the main reference on IT governance for the global business community. 
The goal of the institute is to assist leaders in their responsibility to transform IT into effective support to the mission and organizational objectives. In conducting original research on IT governance and related topics, helps leading companies understand and have tools to ensure effective governance over IT in the enterprise.

Held since 1989, the Annual Survey of Information Technology Resource Management is part of this project of the Center for Applied Computer Science (CIA), and aims to evaluate and study the use and management of IT in enterprises.

The research is conducted with the participation of undergraduate students and graduate from FGV. In 2009, the 5,000 companies surveyed, 2,100 questionnaires were considered valid. The predominance of research refers to medium and large private companies, and in this edition, over $60 \%$ of the five hundred largest companies are represented in the sample.

Through several years of historical research, the quality and quantity of information, are made possible many types of analysis, especially the quantification of indexes for administration and planning of information technology in enterprises.

The main objective of these studies is to quantify and evaluate the evolution of spending on information technology in enterprises, determining the behavior and trends of these indicators for further analysis and forecasts.

One of the main indicators (IT benchmark) of modern management of IT is the total IT spending, measured as a percentage of net revenues of the company, through which it is possible the planning, monitoring and comparison with other companies.

Total expenditure is the sum of all investments, expenses and funds allocated in Informatics, including: equipment, facilities, supplies and consumables, software, services, teleprocessing and direct and indirect costs with its own staff and others working on systems, support and computer training.

Called by the researchers as index G (expenditure and investment / annual net sales), this depends on several factors, being the two main stage or level of computerization and the sector in which the company operates. The stage of computerization has as main components the type, architecture and structure of Information Technology and organizational structure of staff or practiced together, reflecting the level of service, the role and importance of IT for the company.

Graphic 1 shows the evolution in Brazil in the average value of the index G in the last 21 years, with an average growth of $8 \%$ per annum. According to research 
projections, rates must rise in order that the securities in more developed countries are much greater.

Graphic 1 - Evolution of costs and investments in IT - Brazil

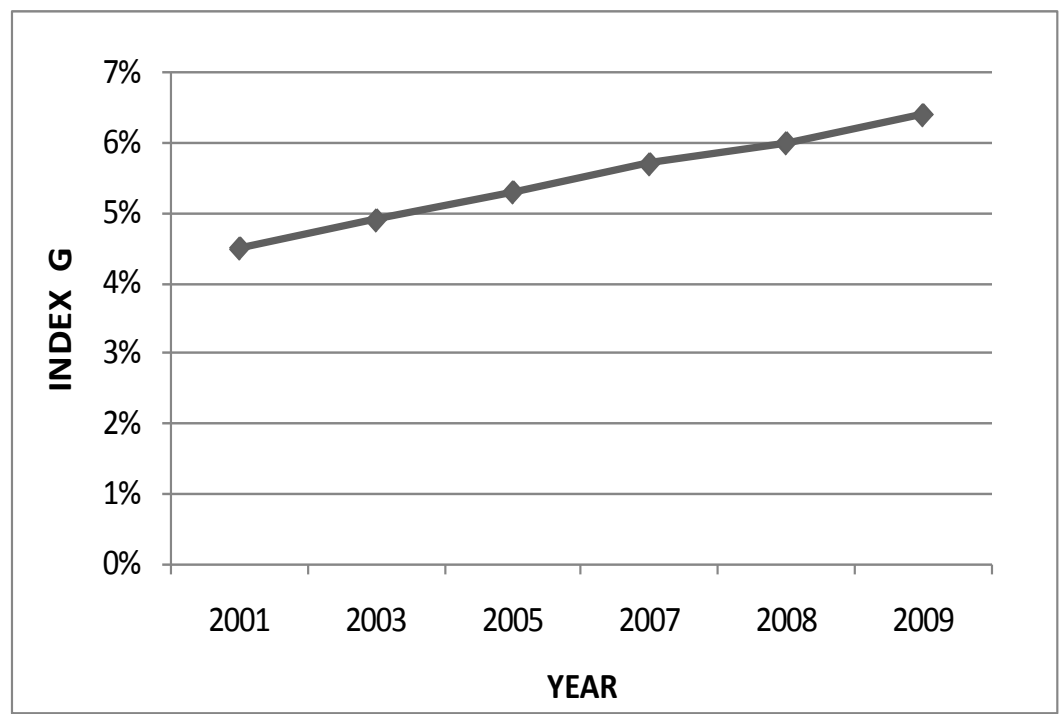

Source: adapted from Meirelles (2010).

Another proposed indicator to complement the former is the annual cost per keyboard (CAPT). It has been highlighted in the literature and consulting specific to IT management and business computing a variation of this indicator: the Total Cost of Ownership (TCO). Specialized companies marketing methodologies for calculation, reduction, evaluation and management in TCO. Figure 3 shows the evolution of the indicator CAPT in recent years. 
Graphic 2 - Evolution of CAPT - Brazil

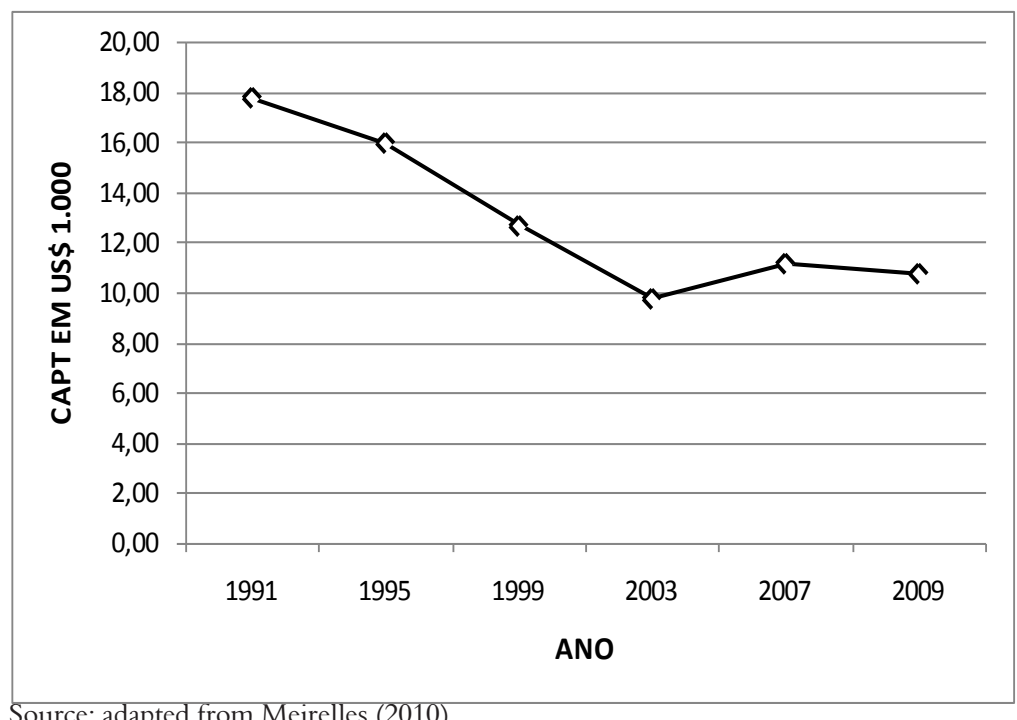

Source: adapted from Meirelles (2010).

On average, the indicator CAPT has decreased in recent years, reaching a value of US\$10,800.00 in 2009 .

\section{CONCEPTUAL MODEL OF RESEARCH}

According to the conceptual model of this study (Diagram 2), we identified the alignment of IT in organizations, as well as IT governance, and calculating the indicators of IT companies in recent years. The purpose was to identify how the indicators could help in improving the alignment and governance, as perceived by managers.

The IT governance is defined by their mechanisms of structure, processes and relationships of organizations (WEILL; WOODHAM, 2002; VAN GREMBERGEN; DE HAES; GULDENTOPS, 2004; PETERSON, 2004; WEILL; ROSS, 2004; DE HAES; VAN GREMBERGEN, 2009).

The indicators were developed with data from recent years of companies such as number of employees, number of IT people, number of keyboards, IT spending and annual net earnings (MEIRELLES, 2010). 


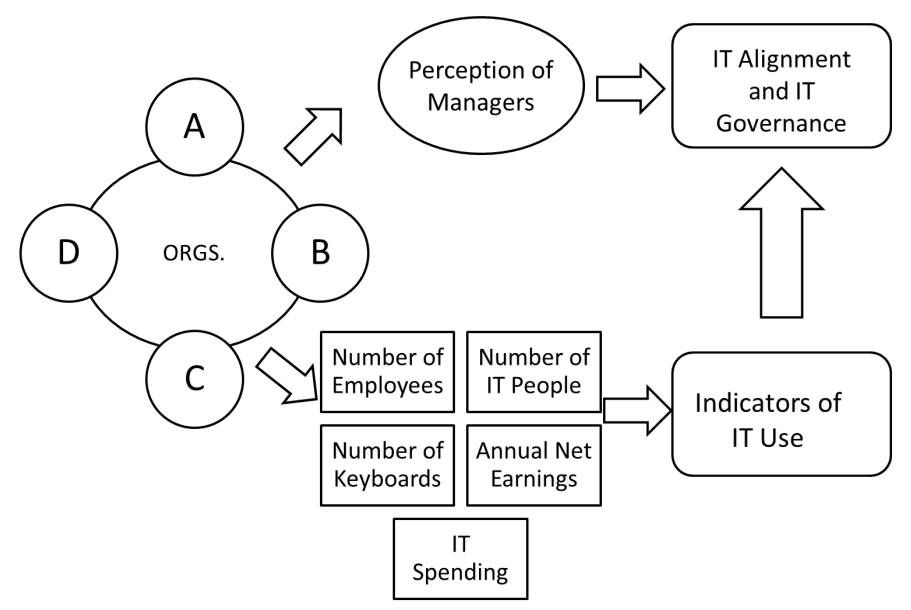

Source: the authors.

\section{METHODOLOGICAL ASPECTS}

Leaving the question: "How the use of indicators of the use of IT can assist in alignment and IT governance?" As well as specific objectives: to ascertain the role of IT, identify the process of IT governance and identify key indicators of use of IT in the organizations surveyed in recent years, it presents the strategy and research design used in this study.

This study used a qualitative methodology with analytical research, with goals of exploratory and descriptive nature.

The view is realistic, positivistic, deterministic, because it provides rational explanations of social relations, and is related to the effective regulation and control of social factors.

To define how to achieve empirical verification of the applicability and adequacy of the analysis model suggested, according to the goals outlined, we performed a literature review of research methods, pointing, as more appropriate method, a multiple case study (YIN, 2005).

The multiple case study brings the ability to guard the vulnerability of a single case (YIN, 2005). It is noteworthy that in multiple cases occur similarities that allow evidence to confirm with greater security, and may be differences that provide a theory of generalization (EISENHARDT, 1989; YIN, 2005). 
Aiming to meet the proposed objectives and for effective data triangulation, different methods were used for data collection (EISENHARDT, 1989; DUBÉ; PARRÉ, 2003; YIN, 2005), such as interactive investigation of the sites, document analysis, bibliography and recorded semi-structured interviews with executives of organizations. The objective was to analyze in a comprehensive and profound research units selected, trying to extract as much information to support the research.

The choice of educational organizations was justified by the fact that they present significant and growing use of IT, computerization of processes for academic and educational records, and also the computerization of educational processes as in the case of distance education.

The organizations selected stand as paradigms of professional education, as well as being similar to the size, goals, lifetime and legal nature and make significant use of IT as an essential part of its activity.

We analyzed the data and information of the last four years (about the stock of IT) from four large educational organizations: organization A, B, C and D.

The evidence for a case study can be obtained from six sources, which are: documents, records on file, interviews, direct observation, participant observation and physical artifacts (YIN, 2005).

To collect the research data were used two sources: a primary source, containing data from semistructured interviews conducted in institutions, and secondary sources, consisting of company documents and website analysis, thereby allowing a triangulation between data.

The researcher conducted interviews with technology managers and business managers of the four organizations. The interviews were full recorded by the researcher using two recorders simultaneously. During transcription, some respondents were contacted for confirmation of information.

Secondary data were obtained through reading and analysis of documents made available on the websites and documents provided by organizations such as: annual reports, production reports, business plans, assessment reports of plans and projects, etc.

Data analysis by the researcher was based in part on the technique of content analysis to identify the presence of high or low partial alignment in each variable.

The procedures adopted for the analysis of content for this research were: (1) initial assessment and interpretation of the data set collected in written documents for familiarization with the jargon and the planning models used by corporate executives, (2) transcription and analysis of recorded interviews and 
notes (3) adequacy of the terminology of the theory, classifying the data collected according to the variables outlined (uniform) and (4) observation and critical analysis of content related to effects not anticipated a priori (REICH; BENBASAT, 1996; CHAN, 1999).

For this study, we used the following attributes: field notes, coding, quotes, design reviews and comparison with similar literature (DUBÉ; PARRÉ, 2003).

\section{RESULTS}

\subsection{CASES STUDIES}

The four educational organizations studied are briefly described:

a) Organization A and B: are nonprofit organizations, private in nature, but with part of its resources come from compulsory contributions set by federal law.

b) Organization $\mathrm{C}$ : is a university community, regional, nondenominational, non-state and not strictly private.

c) Organization D: is a private organization.

\subsection{ANALYSIS OF CASES}

The four organizations analyzed showed consistent similarities in their natures, size and segments. Both have proposals for institutional quality management systems and complex relationships which make use of information technology for its adequate care. The indicators of IT use in cases A, B and C are slightly above the sector but are also congruent. In case $\mathrm{C}$, the indicators are very close to the sector average. In both cases, there is enough line between the main perceptions of managers, compared with managers of business areas.

It is noteworthy that the indicators of IT use applied to this research relate to the education sector, with a clipping of the Annual Survey of Information Resources Management, provided by the FGV-EAESP.

Internal processes and tools used have small differences between the organizations, it was found in research that both are constantly promoting continuous improvement, for the improvement of indicators, which are the same of the main 
tools for managing IT governance, yet deemed that none of the organizations surveyed assume that has formalized and installed a system of ITG. A final element congruent, which perhaps explains the fact that three of the four organizations have indicators above the sector average, which is required for uses of technology also, and especially in educational activity, which is common element of the performance of these enterprises, which directly impacts on Index $\mathrm{G}$ and also on display CAPT.

Table 1 presents a comparison of recent years.

Table 1 - Comparative Index G

\begin{tabular}{crrrrr}
\hline $\begin{array}{c}\text { Index } \\
\text { Organiza- } \\
\text { tions }\end{array}$ & \multicolumn{1}{c}{ 2005 } & \multicolumn{2}{c}{ Index G (\%) } & \\
\hline A & 15.70 & 15.60 & 14.60 & 13.90 & - \\
B & 8.00 & 9.00 & 10.00 & 12.00 & 16.00 \\
C & 9.50 & 10.00 & 10.50 & 11.00 & 11.00 \\
D & 7.00 & 7.50 & 5.00 & 7.50 & 8.00 \\
Average & 7.50 & 7.70 & 8.10 & 8.50 & 9.50 \\
\hline Source: the authors & & & & &
\end{tabular}

The indicator of Annual Cost for Keyboard (CAPT), the Organizations have values lower than the sector average, because it characterized as educational, which interferes in the values of the indicator, because in them there is lots of computers for education.

Table 2 - Comparative Annual Cost for Keyboard

\begin{tabular}{ccccrr}
\hline $\begin{array}{c}\text { Index } \\
\text { Organizations }\end{array}$ & \multicolumn{2}{c}{ CAPT } \\
\hline A & 5.40 & $\mathbf{2 0 0 6}$ & $\mathbf{2 0 0 7}$ & \multicolumn{2}{c}{$\mathbf{2 0 0 8}$} \\
B & 3.22 & 5.92 & 6.72 & 7.02 \\
C & 6.54 & 6.24 & 4.03 & 5.32 \\
D & 6.00 & 6.50 & 7.20 & 7.50 \\
Average & 9.99 & 10.00 & 6.50 & 6.90 \\
\hline
\end{tabular}

Analyzing the indicators of organizations and the sector average, some conclusions were possible.

With respect to the $G$ index, the percentage of investments of the Organization is well above the sector average, since 2005, however, is declining, 
which is consistent with the position of IT manager of the institution, which intends to reduce such values, matching them to the educational average.

In the case of Organization B, the index values of $\mathrm{G}$ in 2005 are very close to the sector average, but the company is increasing its investments every year, reaching a value much higher than the 2009 average. The IT director confined itself to this fact, questioning them about the need to review some points. The Organization $\mathrm{C}$ was a little above average in the years 2005 and 2006, but is approaching the average in recent years. Already the Organization D is the one that most closely matches the sector average, despite a fall in 2007.

The indicator CAPT, although the difference between business and media, can analyze the evolution of the indicator in all cases are consistent, with a gradual increase without major changes.

\subsection{DISCUSSION OF THE RESULTS}

The results of technology indicators of the organizations studied indicate that managers have consistency in their decisions and choices and keeps track of their technology investments.

Despite the difficulty of measuring the investments and not having the calculated indicators, the strategy mentioned in relation to technology were aligned with the calculated values of organizations.

In some specific years, investments were higher due to a larger investment required, but when calculating the sequence of four years, all organizations presented a technology alignment with very good business strategy.

\section{FINAL REMARKS}

In the cases studied, in the perception of executives, the indicators of IT use are clearly seen as important for IT governance and alignment, and their own quality management, integrating corporate governance.

There is a widespread perception that the indicators can serve as a comparative basis with other firms (benchmark) in the same sector, or with the sector average, serving as a parameter for the amount of investments and technology options being used (suppliers, software, hardware, etc.). 
Another relevant factor is the possibility of comparing the historical development of internal indicators within the organization, enabling more accurate strategic planning and monitoring or constant monitoring, avoiding the demands that emerge as problematic only when some emergency indicator reaches its critical level.

In the survey, was appointed by the managers the applicability of such indicators as elements of trading compared to the sector average, in situations that require investment in technology. You can use the indicators as justifications, when discussing the possibility of being affected values determined in the indicators.

The monitoring indicators of IT use and GTI, the integrated quality management or corporate governance, gives IT managers a better position to negotiate with suppliers who will always offer solutions that seemingly solve all organizational problems, but rarely are confirmed with the same effectiveness and reasonable cost.

For governance technology, the indicators allow greater control in decisions on investment and in which process the money should be invested. This compared with investment of other enterprises, with an idea of the percentage invested in each process, facilitates the decisions of managers. Companies are different and also the strategies thus must use the indicators as a parameter, but the alignment of business strategy with technology strategy is critical. Companies with greater emphasis on innovation in technology likely to have indicators superior to competitors, and this should be analyzed with caution.

Some authors argue that the case study need not necessarily generate generalizations of their findings; the fundamental becomes how the other researchers will use that case, doing what is called "naturalistic generalization" (STAKE, 1982; MARIOTTO; ZANNI; MORAES, 2014). The idea of "naturalistic generalization" supports the notion of generalization as transferability, Lincoln and Guba (2000). For transferability it should be understood, not the reproduction of results (generalization) under the same conditions were maintained in previous studies, but the possibility of use of procedures and results in similar situations, respecting the peculiarities of the new contexts.

Thus, this study suggests that the most correct is that the reader identifies the similarities of the contexts to reproduce the findings of the study.

For Lincoln and Guba (1985, 2000), the researcher's responsibility is to provide sufficient contextual information to facilitate the prosecution of the reader as to whether a particular case can be generalized to a specific field of practice. To Stake (1982), which is required of investigators of the case study is 
not to provide generalizations, but illustrating the case adequately, capturing their unique characteristics. That was the idea of the study, to provide the maximum of background information, to assist in judging the readers.

Some considerations regarding the limitations of the research are necessary, namely: perceptual skills of the researcher, both aspects and explanations addressed in the literature, the interpretive capacity of the collection and analysis of the study; reduced number of respondents, focusing on the chief executive of IT and an executive from the business area, selection of only four organizations in the sector, reaching hasty conclusions, and analysis and the absence of an adequate structure of GTI in organizations, which hinders the understanding of it by the interviewees and research analysis.

\section{REFERENCES}

ALI, S.; GREEN, P. Effective Information Technology (IT) Governance Mechanisms: an IT Outsourcing Perspective. Information Systems Frontiers, v. 14, i. 2, p. 179-193, 2012.

BACON, C. The use of decision criteria in selecting information systems/ technology investments. MIS Quarterly, v. 16, i. 3, p. 335-353, Sept. 1992.

BAROTO, M. B.; ABDULLAH, M. M. B.; WAN, H. L. Hybrid Strategy: A New Strategy for Competitive Advantage. International Journal of Business and Management, v. 7, i. 20, 2012.

BIRD, F. Good Governance: A Philosophical Discussion of the Responsibilities and Practices of Organizational Governors. Canadian Journal of Administrative Sciences, v. 18, i. 4, p. 298-312, Dec. 2001.

BLOEM, J.; VAN DOORN, M.; MITTAL, P. Making IT governance work in a Sarbanes-Oxley world. New Jersey: John Wiley \& Sons, 2006.

BOWEN, P. L.; CHEUNG, M-Y. D.; ROHDE, F. H. Enhancing IT Governance Practices: a Model and Case Study of an Organization's Efforts, International Journal of Accounting Information Systems, v. 8, i. 3, p. 191-221, 2007.

BRADLEY, R. V. et al. An Empirical Examination of Antecedents and Consequences of IT Governance in U.S. Hospitals. Journal of Information Technology, v. 27, i. 2, p. 156-177, 2012. 
BRANCHEAU, J.; WETHERBE, J. Issues In Information Systems Management. MIS Quarterly, v. 11, i. 1, p. 23-45, 1987.

BRODBECK, A. F.; HOPPEN, N. Alinhamento Estratégico entre os Planos de Negócio e de Tecnologia de Informação: Um Modelo Operacional para Implementação. Revista de Administração Contemporânea - RAC, v. 7, n. 3, p. 9-33, jul./set. 2003.

BROWN, A.; GRANT, G. Framing the frameworks: a review of IT governance research. Communications of the Association for Information Systems, v. 15, p. 696-712, 2005.

CHAN, Y. E. IS strategic and strutuctural alignment: eight case studies. In: AMERICAS CONFERENCE ON INFORMATION SYSTEMS, 1999, Wisconsin. Proceedings... Wisconsin: Association for Information Systems, 1999. 1 CD-ROM.

CHAN, Y.; HUFF, S. Strategic Information Systems Alignment. Business Quarterly, v. 58, i. 1, p. 51-56, 1993.

CHUNG, S. H.; RAINER, R. K.; LEWIS, B. R. The impact of Information Technology Infrastructure flexibility on strategic alignment and applications implementation. Communications of the Association for Information Systems, Atlanta, v. 11, p. 1-30, 2003.

DE HAES, S.; VAN GREMBERGEN, W. An Exploratory Study into IT Governance Implementations and its Impact on Business/IT Alignment. Information Systems Management, v. 26, i. 2, p. 123-137, Spring 2009.

DEHNING, B.; DOW, K. E.; STRATOPOULOS, T. Information technology and organizational slack. International Journal of Accounting Information Systems, v. 5, i. 1, p. 51-63, May 2004.

DELONE, W. H.; MCLEAN, E. R. Information systems success: the quest for the dependent variable. Information Systems Research. v. 3, i. 1, p. 60-95, 1992.

DELONE, W. H.; MCLEAN, E. R. The DeLone and McLean model of information systems success: a ten-year update. Journal of Management Information Systems, v. 19, i. 4, p. 9-30, Spring, 2003.

DEVARAJ, S.; KOHLI, R. The IT payoff: measuring the business value of information technology investments. New York: Prentice Hall, 2002.

DIXON, P.; JOHN, D. Technology Issues Facing Corporate Management in the 1990s. MIS Quarterly, v. 13, i. 3, p. 247-55, 1989. 
DUBÉ, L.; PARRÉ, G. Rigor in information systems positivist case research: current practices, trends, and recommendations. MIS Quarterly, v. 27, i. 4, p. 597-635, Dec. 2003.

EISENHARDT, K. M. Building theories from case study research. Academy of Management Review, v. 14, i. 4, p. 532-550, 1989.

EVANS, P. B.; WURSTER, T. S. Getting Real about virtual Commerce. Harvard Business Review, v. 77, i. 6, p. 84-94, Nov./Dec. 1999.

FITZGERALD, G. Evaluating information systems projects: a multidimensional approach. Journal of Information Technology, v. 13, i. 1, p. 15-27, Mar. 1998.

HENDERSON, J. C.; VENKATRAMAN, N. Strategic Alignment: Leveraging Information Technology For Transforming Organizations. IBM Systems Journal, v. 32, i. 1, p. 4-16, 1993.

\section{HENDERSON, J.; VENKATRAMAN, N. Aligning Business and IT}

Strategies. Competing in the Information Age, Luftman, New York, Oxford University Press, 1996.

HUANG, R.; ZMUD, R. W.; PRICE, R. L. Influencing the Effectiveness of IT Governance Practices through Steering Committees and Communication Policies, European Journal of Information Systems, v. 19, i. 3, p. 288-302, 2010.

INFORMATION TECHNOLOGY GOVERNANCE INSTITUTE. Board briefing on IT governance. 2nd ed. Rolling Meadows, 2003.

INFORMATION TECHNOLOGY GOVERNANCE INSTITUTE. An Executive View of IT Governance. 2009. Available in: <www.itgi.org>. Accessed in: May 5, 2010,

IVES, B.; JARVENPAA, S.; MASON, R. Global Business Drivers: Aligning Information Technology to Global Business Strategy. IBM Systems Journal, v. 32, i. 1, p. 143-161, 1993.

KARIMI, J. et al. The Effects of MIS Steering Committees on Information Technology Management Sophistication, Journal of Management Information Systems, v. 17, i. 2, p. 207-230, 2000.

LAZIC, M. et al. The Impact of IT Governance on Business Performance. In: PROCEEDINGS OF THE 2011 AMERICAS CONFERENCE ON INFORMATION SYSTEMS, 2011, Detroit. Proceedings... Detroit, 2011.

LINCOLN, Y.; GUBA, E. Naturalistic inquiry. Newbury Park, CA: Sage, 1985. 
LINCOLN, Y.; GUBA, E. The only generalization is: There is no generalization. In: GOMM, R.; HAMMERSLEY, M; FOSTER, P. (Ed.). Case Study Method. London: Sage, 2000.

LUFTMAN, J.; PAPP, R.; BRIER, T. Enablers and Inhibitors of Business - IT Alignment. Communications of the Association for Information Systems, Atlanta, v. 1, i. 11, Mar. 1999.

LUNARDI, G. L.; BECKER, J. L.; MAÇADA, A. C. G. The Financial Impact of IT governance Mechanisms' Adoption: An Empirical Analysis with Brazilian Firms. In: HAWAII INTERNATIONAL CONFERENCE ON SYSTEM SCIENCES (HICSS). 42., 2009. Proceedings... Waikoloa, 2009.

MARIOTTO, F. L.; ZANNI, P. P.; MORAES, G. H. S. M. What is the use of a single-case study in management research? ERA - Revista de Administração de Empresas, v. 54, p. 358-369, 2014.

MATLIN, G. What is the value of investment in information systems? MIS Quarterly, v. 3, i. 3, p. 5-34, Sept. 1979.

MARCHAND, D. Reaping the business value of IT. Business \& Economic Review, July/Sept. 2005.

MCFARLAN, F.; McKENNEY, J.; PYBURN, P. The Information Archipelago - Plotting a Course. Harvard Business Review, v. 61, i. 1, p. 145-156, Jan./Feb. 1983.

MCLEAN, E.; SODEN, J. Strategic Planning for MIS. New York: John Wiley \& Sons, 1977.

MEIRELlES, F. S. Pesquisa Anual de Administração de Recursos de Informática. 21. ed. São Paulo: FGV-EAESP-CIA, 2010. Available in: <www.fgv. br/cia/pesquisa >. Accessed in: Sept. 5, 2014.

\section{MEIRELleS, F. S. Pesquisa Anual de Administração de Recursos de} Informática. 26. ed. São Paulo: FGV-EAESP-CIA, 2015. Available in: <www.fgv. $\mathrm{br} / \mathrm{cia} /$ pesquisa $>$. Accessed in: Sept. 5, 2014.

MEYER, N. D. Systemic is Governance: an introduction. Information Systems Management, v. 21, i. 4, p. 23-34, Fall 2004.

MILLS, P. Managing Service Industries. New York Ballinger, 1986. 
MITCHELL, S. M.; SHORTELL S. M. The Governance and Management of Effective Community Health Partnership: A Typology for Research, Policy, and Practice. The Milbank Quarterly, v. 78, i. 2, p. 241-289, 2000.

NEUMANN, S.; AHITUV, N.; ZVIRAN, M. A Mesure for Determinig the Strategic Relevance of IS to the Organization. Information \& Management, v. 22, i. 5, p. 281-299, May 1992.

NIEDERMAN, F.; BRANCHEAU, J.; WETHERBE, J. Information Systems Management Issues For the 1990s. MIS Quarterly, v. 15, i. 4, p. 475-95, 1991.

ORLIKOWSKI, W. J. Using technology and constituting structures: a practice lens for studying technology in organizations. Organization Science, v. 11, i. 4, p. 404-428, July/Aug. 2000.

PAPP, R. Assessing Strategic Alignment in Real Time. Journal of Informatics Education Research, v. 6, i. 1, 2004.

PETERSON, R. R. Integration strategies and tactics for information technology governance. In: VAN GREMBERGEN, W. Strategies for information technology governance. Hershey: Idea group publishing, 2004.

PORTER, M. E. Strategy and the internet. Harvard Business Review, v. 79, i. 1, p. 63-78, Mar. 2001.

PRASAD, A.; GREEN, P.; HEALES, J. On IT Governance Structures and Their Effectiveness in Collaborative Organizational Structures, International Journal of Accounting Information Systems, v. 13, p. 199-220, 2012.

REICH, B. H.; BENBASAT, I. Measuring the linkage between business and information technology objectives. MIS Quarterly, v. 20, i. 1, p. 55-81, Mar. 1996.

ROBSON, W. Strategic Management and Information Systems: An Integrated Approach. London: Pitman Publishing, 1994.

ROGERS, L. Alignment Revisited. CIO Magazine, May 15, 1997.

SCHWARZ, A.; HIRSCHHEIM, R. An Extended Platform Logic Perspective of IT Governance: Managing Perceptions and Activities of IT. Journal of Strategic Information Systems, v. 12, i. 2, p. 129-166, July 2003.

SOHAL, A.; FITZPATRICK, P. IT Governance and Management in large Australian Organizations. International Journal of Production Economics, v. 75, i. 1, p. 97-112, 2002. 
STAKE, R. Naturalistic generalization. Review Journal of Philosophy and Social Science, v. 7, p. 1-12, 1982.

VAN GREMBERGEN, W.; DE HAES, S.; GULDENTOPS, E. Structures, Processes and Relational Mechanisms for IT Governance. In: VAN GREMBERGEN, Win (Ed.). Strategies for Information Technology Governance. Hershey, PA, USA: Idea Group Publishing, 2004.

WATSON, R.; BRANCHEAU, J. Key Issues In Information Systems Management: An International Perspective. Information \& Management, v. 20, p. 213-223, 1991.

WARD, J.; TAYLOR, P.; BOND, P. Evaluation and realization of IS/IT Benefits: an empirical study of current practices. European Journal of Information Systems, v. 4, p. 215-225, 1996.

WEILL, P. Don't just lead govern: how top-performing firms govern IT. MIS Quarterly Executive, v. 3, i. 1, p. 1-17, Mar. 2004.

WEILL, P.; OLSON, M. Managing investment in information technology: mini case examples and implications. MIS Quarterly, v. 13, i. 1, p. 3-17, Mar. 1989.

WEILL, P.; ROSS, J. W. IT Governance: how top performers manage IT decision rights for superior results. Boston, Massachusetts, USA: Harvard Business School Press, 2004.

WEILL, P.; WOODHAM, R. Don't Just Lead, Govern: Implementing Effective IT Governance. WP, n. 326. Cambridge, Massachusetts: Massachusetts Institute of Technology, 2002.

WU, S. P.; STRAUB, D. W.; LIANG, T. P. How information technology governance mechanisms and strategic alignment influence organizational performance: insights from a matched survey of business and it managers. MIS Quarterly, v. 39, i. 2, p. 497-518, 2015.

YIN, R. K. Estudo de caso: planejamento e métodos. Porto Alegre: Bookman, 2005.

\section{Sponsoring information}

This research was supported by: Espaço da Escrita / Coordenadoria Geral da UNICAMP.Como citar este artigo: 


\section{COMO CITAR ESTE ARTIGO}

MORAES, Gustavo Hermínio Salati Marcondes de. Indicators of technology in the perception of it and business managers - a comparative analysis. RACE, Revista de Administração, Contabilidade e Economia, Joaçaba: Ed. Unoesc, v. 14, n. 3, p. 863-888, set./dez. 2015. Disponível em: < http://editora.unoesc.edu. br/index.php/race $>$. Acesso em: dia/mês/ano.

Moraes, G. H. S. M. Indicators of technology in the perception of it and business managers - a comparative analysis. RACE, Revista de Administração, Contabilidade e Economia, 14 (3), 863-888. Recuperado em dia/mês/ano, de http://editora.unoesc. edu.br/index.php/race 
